\title{
Strategi Kepala Sekolah Dalam Peningkatan Motivasi Belajar Siswa Pada Masa Pandemi Covid 19 di SMPN 2 Peterongan Jombang
}

\author{
Dita Dzata Mirrota \\ dzmirrota@gmail.com \\ STIT Al-Urwatul Wutsqo Jombang \\ Khanna Qothrun Nada \\ STIT Al-Urwatul Wutsqo Jombang
}

\begin{abstract}
This study aims to describe the principal's strategy in increasing student learning motivation during the covid 19 pandemic at SMPN 2 Peterongan Jombang. The method used in this study uses qualitative field research (field research). This study used a qualitative descriptive research design. Data collection techniques used interview, observation, and documentation techniques. Furthermore, data analysis was carried out using qualitative descriptive analysis methods, namely in the form of written presentation of data regarding related data. The results showed that: 1). The motivations possessed by students at SMPN 2 Peterongan Jombang during the covid 19 pandemic were students who were enthusiastic in learning, felt the need for knowledge or without coercion, had aspirations or hopes for the future, motivated by gifts or awards. given, motivated by interesting learning. 2). The strategy of the principal of SMPN 2 Peterongan in increasing students' learning motivation during the covid 19 pandemic, namely: The principal makes plans regarding active learning steps, the principal holds meetings with teachers and also associations with students as well as parents at school in turn regarding understanding of online system learning, Adding assignments to students that are practical at home, Providing qualitative assessments to students, namely neatness, accuracy and honesty who are diligent, less diligent, not diligent and so on.
\end{abstract}

Keywords: Principal Strategy, School Motivation, Covid 19 Pandemic

\section{Pendahuluan}

Sejak pemerintah Indonesia mengumumkan mengenai kasus pertama corona virus desease 2019 (covid 19) pada bulan maret 2020 yang lalu, Indonesia dihadapkan pada masa pandemi (Munastiwi, 2020). Hampir seluruh sektor kehidupan terdampak dari perusahaan, pemasaran, perekonomian masyarakat 
dan lain-lain, tidak terkecuali disektor pendidikan, karena pendidikan sangat penting. Pada aspek pendidikan, pemerintah melalui Kementerian Pendidikan dan Kebudayaan (Kemendikbud) telah menerapkan kebijakan learning for home atau belajar dari rumah, terutama bagi satuan pendidikan yang berada di wilayah zona kuning, merah dan hitam. Bagi satuan pendidikan yang berada di zona hijau, dapat melaksanakan pendidikan dengan mengarah kepada protokol Kesehatan. ${ }^{1}$

Berdasakan fenomena tersebut suasana dan proses pendidikan mengalami perubahan, perubahan tersebut dilatarbelakangi oleh maraknya wabah covid 19 sehingga menjadi kendala terjalinnya hubungan sosial maupun emosional secara lansung dalam pendidikan di Indonesia. Pandemi covid 19 diharapkan tidak membuat pelaksanaan pendidikan kita terkendala, mengingat bantuan teknologi hari ini dapat mendukung terciptanya pelaksanaan pembelajaran dengan siswa. Guru juga dapat menerapkan metode hypnoteaching untuk peningkatan motivasi belajar siswa ${ }^{2}$ dengan tetap mengikuti anjuran pemerintah untuk menerapkan protokol kesehatan pada era pandemi covid 19.3

Pemerintah Indonesia melalui Menteri Pendidikan dan Kebudayaan (Mendikbud) telah mengeluarkan Surat Edaran (SE) Nomor 4 Tahun 2020 Tentang Pelaksanaan Kebijakan Pendidikan dalam Masa Darurat Penyebaran Coronavirus Disease. ${ }^{4}$ Terbitnya Surat Edaran ini sebagai bentuk tindakan pencegahan penularan Covid 19 di lingkungan Pendidikan yang mengartikan bahwa pemerintah peduli terhadap faktor Pendidikan dan kesehatan lahir batin dari seluruh warga sekolah. Salah satu isi dari Surat edaran tersebut menyatakan bahwa kegiatan pembelajaran selama masa pandemi dilakukan di rumah, baik secara daring (dalam jaringan) maupun luring (luar jaringan) atau disebut dengan pembelajaran jarak jauh (PJJ).

Sebagai kepala sekolah, sepatutnya tetap bisa mengontrol bawahannya mulai dari pendidik serta tenaga kependidikan dan utamanya siswa meskipun pada masa pandemi, karena betapa pentingnya motivasi belajar siswa, karena jika siswa

\footnotetext{
1 Muhammad Sufyan Ats-Tsauri and Erni Munastiwi, "Strategi Kepala Madrasah Dalam Menentukan Kebijakan Pembelajaran Era Covid 19 Studi Kasus Kepala Madrasah Ibtidaiyah NW Pondok Gedang," Elementeris: Jurnal Ilmiah Pendidikan Dasar Islam 2, no. 2 (2020): 55-61.

2 Buana Sari, Baiq Arnika Sa'adati, and Muhamad Sadli, "Peningkatan Motivasi Belajar Siswa Melalui Penerapan Metode Hypnoteaching Pada Mata Pelajaran Ips Siswa Kelas V Sd Nurul Ijtihad Pujut Lombok Tengah," Elementeris: Jurnal Ilmiah Pendidikan Dasar Islam 1, no. 2 (2019): 10-18.

3 Johandri Taufan and Fachri Mazhud, "Kebijakan-Kebijakan Kepala Sekolah Dalam Penyelenggaraan Pendidikan Inklusif Di Sekolah X Kota Jambi," Jurnal Penelitian Pendidikan 14, no. 1 (2016).

4 MPDAN KEBUDAYAAN and REPUBLIK INDONESIA, "Surat Edaran Nomor 4 Tahun 2020 Tentang Pelaksanaan Kebijakan Pendidikan Dalam Masa Darurat Penyebaran Coronavirus Disease (COVID-19)," Khomariyah, KN, \& Afia, UN (2020). DIGITALISASI DALAM PROSES PEMBELAJARAN SEBAGAI DAMPAK ERA KEBERLIMPAHAN. ISoLEC Proceedings 4, no. 1 (2020): 72-76.
} 
semangat dalam belajar untuk mencari ilmu Allah akan meninggikan beberapa derajad seperti dalam firman Allah dalam surat al-Mujadalah ayat 11 yang berbunyi:

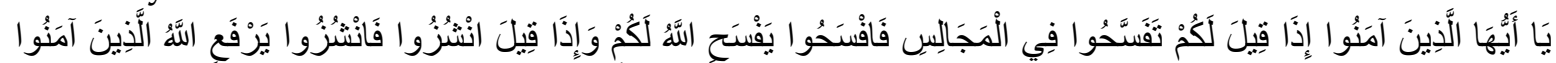

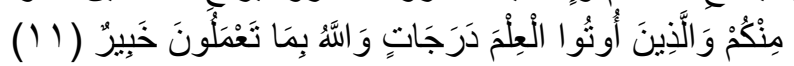

Artinya: "Hai orang-orang beriman apabila kamu dikatakan kepadamu: "Berlapang-lapanglah dalam majlis", Maka lapangkanlah niscaya Allah akan memberi kelapangan untukmu. dan apabila dikatakan: "Berdirilah kamu", Maka berdirilah, niscaya Allah akan meninggikan orang-orang yang beriman di antaramu dan orang-orang yang diberi ilmu pengetahuan beberapa derajat. dan Allah Maha mengetahui apa yang kamu kerjakan." (Kementerian Agama RI, 2012).

Kepala sekolah sebagai pemimpin Lembaga pendidikan harus memiliki kesiapan dalam menghadapi dan beradaptasi terhadap tantangan-tantangan yang datang dalam situasi apapun termasuk pandemi Covid 19 yang saat ini sedang terjadi. Kepala sekolah perlu merancang langkah-langkah strategis dalam peningkatan motivasi belajar siswa di sekolah yang dipimpinnya pada masa pandemi Covid 19. Langkah strategi ini disebut sebagai strategi kepemimpinan yang dapat berupa suatu kebijakan yang diambil oleh kepala sekolah sebagai respon terhadap situasi pandemi yang terjadi. ${ }^{5}$

Pandemi Covid 19 menjadi tantangan kepala sekolah yang semakin besar, di mana ekonomi yang berdampak pada pembayaran sekolah, serta kesibukan orang tua yang bertambah akibat harus membimbing anaknya belajar, tingkat penguasaan teknologi dari orang tua yang berbeda-beda, serta kebingungan guru dalam metode pembelajaran online yang tepat untuk anak agar tetap menyenangkan belajar di rumah. Karena pada dasarnya anak akan belajar apabila menyenangkan dan menarik. ${ }^{6}$

Motivasi belajar sangat di perlukan siswa agar mencapai hasil belajar yang maksimal. Motivasi dan belajar merupakan dua hal yang saling memengaruhi. Siswa akan giat belajar jika ia mempunyai motivasi untuk belajar. Belajar sebagai proses interaksi antara stimulus (yang mungkin berupa pikiran, perasaan, atau gerakan) dan respon. Belajar merupakan suatau proses atau interaksi yang

\footnotetext{
${ }^{5}$ Siti Khodijah and Mohammad Syahidul Haq, "Strategi Kepemimpinan Kepala Sekolah Dalam Meningkatkan Mutu Pendidikan Di Masa Pandemi Covid-19," n.d.

6 Syaifudin Noer, Evi Fatimatur Rusydiyah, and Fachrizal Hamzah, "Model Ilhamq (Model Menghafal Al Quran Berbasis Game) Di SMP Insan Cendekia Mandiri Boarding School Sidoarjo," Nusantara Journal of Islamic Studies (NJIS) 1, no. 2 (2020): 1-10.
} 
dilakukan seseorang dalam memperoleh sesuatu yang baru dalam bentuk perubahan perilaku sebagai hasil dari pengalaman belajar. ${ }^{7}$

Motivasi belajar merupakan dorongan yang menggerakan individu untuk bertingkah laku, melakukan kegiatan belajar dan kelangsungan dari kegiatan untuk mencapai tujuan pembelajaran. Motivasi belajar merupakan faktor penting yang harus dimiliki siswa. Siswa yang menyadari pentingnya motivasi belajar dapat memperlancar tercapainya tujuan dalam pembelajaran. Apabila motivasi belajar sudah tertanam dalam diri siswa akan memudahkan siswa dalam belajar secara terarah dan teratur serta dapat menunjang keberlangsungan proses pembelajaran, motivasi belajar yang tinggi dapat berdampak terhadap hasil belajar siswa. Peran motivasi dalam proses pembelajaran, motivasi belajar siswa dapat dianalogikan sebagai bahan bakar untuk menggerakkan mesin. Motivasi belajar yang memadai akan mendorong siswa berperilaku aktif untuk berprestasi dalam kelas. ${ }^{8}$

Hasil penelitian widiyono (2020) menunjukkan bahwa kegiatan pembelajaran daring mengakibatkan pembelajaran yang kurang efektif. Hal ini serupa dengan paparan dokumen penyesuaian kebijakan pembelajaran di masa pandemi covid 19 komite penanganan covid 19 dan pemulihan ekonomi nasional (2020) menjelaskan bahwa berdasarkan hasil studi yang telah dilakukan, kegiatan pembelajaran jarak jauh atau pembelajaran yang tidak dilakukan secara tatap muka langsung dapat menciptakan penurunan hasil belajar serta dapat menghasilkan pencapaian akademik yang lebih buruk dibandingkan dengan kegiatan pembelajaran yang dilakukan di sekolah secara tatap muka langsung.

\section{Metode Penelitian}

Penelitian yang akan dilakukan peneliti ini berupakan penelitian lapangan (field research) juga disebut dengan penelitian kualitatif. ${ }^{9}$ Penelitian ini menggunakan teknik pengumpulan data meliputi pertama, Observasi. ${ }^{10}$ Teknik ini digunakan untuk memperoleh data tentang motivasi siswa pada masa pandemi covid 19 dan bagaimana startgi kepala sekolah dalam peningkatan motivasi belajar siswa pada masa pandemi covid-19 di SMPN 2 Peterongan. Kedua, Wawancara. ${ }^{11}$ Wawancara dilakukan terhadap pihak-pihak yang dapat

\footnotetext{
7 Serli Mahardika and Fery Setyaningrum, "Analisis Faktor Penyebab Kesulitan Belajar Pada Pembelajaran Bahasa Jawa Kelas V Sd Muhammadiyah Bausasran Ii Yogyakarta," Jurnal Fundadikdas (Fundamental Pendidikan Dasar) 3, no. 3 (2020): 251-59.

8 cintami Farmawati And Siti Nureliza, "Ketrampilan Komunikasi Guru Dalam Meningkatkan Motivasi Belajar Siswa Di Kelompok Bermain Mahardika," Jurnal Lentera Anak 1, no. 01 (2020).

${ }^{9}$ Lexy J Moleong, Metodologi Penelitian Kualitatif (PT Remaja Rosdakarya, 2021).

${ }^{10}$ Dr Sugiyono, “Metode Penelitian Pendidikan Pendekatan Kuantitatif, Kualitatif Dan R\&D," 2013.

${ }^{11}$ Moleong, Metodologi Penelitian Kualitatif.
} 
memberikan informasi yang berkaitan dengan objek penelitian yang mengenai strategi kepala sekolah dalam peningkatan motivasi belajar siswa pada masa pandemi covid 19, yang peneliti jadikan informan di antaranya yaitu: kepala sekolah, wali kelas VIII D dan siswa-siswi kelas VIII D SMPN 2 Peterongan. Ketiga, Dokumentasi. ${ }^{12}$ Agar dapat informasi mengenai hal dalam dokumentasi, arsip, foto, buku yang terkait tentang strategi kepala sekolah dalam meningkatkan motivasi belajar siswa pada masa pandmi covid 19 di SMPN 2 Peterongan.

Uji keabsahan data dalam peneliti ini ditentukan dengan menggunakan uji kredibilitas (derajat kepercayaan). Dalam menguji keabsahan data penelitian ini, peneliti menggunakan beberapa tahap, diantaranya: Triangulasi dan diskusi Teman. Teknik Analisis Data antara lain data reduction, data display, verification/conclusion drawing.

\section{Hasil Penelitian}

\section{Strategi kepala sekolah dalam peningkatan motivasi belajar siswa pada masa} pandemi covid 19 di SMPN 2 Peterongan Jombang

a. Merancang, menentukan, menyusun dan mengimplementasikan pembelajaran untuk mencapai tujuan pembelajaran.

Dalam perencanaan strategi diera pandemi yang sudah dibuat oleh kepala sekolah adalah persiapan perencanaan strategi dalam pembelajaran daring kepada siswa dengan menggunakan alat media sosial sebagai sarana pembelajaran serta pola pembelajarannya didasarkan pada tujuan yang diharapkan dimana tujuan pembelajaran adalah selain untuk meningkatkan pengetahuan siswa juga bisa merubah kebiasaan atu tingkah laku siswa hal ini sesuai dengan pernyataan kimble dan garmezi tentang pengertian belajar bahwasanya belajar merupakan perubahan tingklah laku yang bersikap tetap yang berlansung dari pengalaman oleh karena itu persiapan yang disusun oleh sekolah hendaknya disesuiakan dengan keadaan dan situasi sekarang ini.

Dari hasil wawancara, bisa diambil kesimpulan bahwa strategi kepala sekolah dalm peningkatan motivasi belajar siswa SMPN 2 Peterongan pada masa pandemi covid 19 yaitu dengan membuat perencanan terlebih dahulu, karena suatu manajemen itu pasti diawali dengan perencanaan, di sini kepala sekolah membuat perencanaan mengenai langkah-langkah pembelajarn aktif.

\footnotetext{
12 Sugiyono, “Metode Penelitian Pendidikan Pendekatan Kuantitatif, Kualitatif Dan R\&D.”
} 
b. Memberikan pemahaman kepada guru dan siswa mengenai mekanisme pembelajaran daring

Implmentasi pembelajaran daring mengacu kepada kebijakan dan peraturan pemerintah dan kebijakan kepala sekolah menganai pembelajaran daring. Dalam situasi dan kondisi yang terjadi saat ini masa pandemic bukanlah menjadi kendala pelaksanaan proses belajar mengajar. Namun bagaiamana kita mampu membaca situasi dan memanfaatkan media sosial sebagi media pembelajaran sehingga pembelajaran dimasa pandemi ini tetap terlaksana seuai tujuan pembelajaran yang diharapakan.

Dari hasil wawancara di atas, bisa diambil kesimpulan bahwa strategi kepala sekolah dalm peningkatan motivasi belajar siswa SMPN 2 Peterongan pada masa pandemi covid 19 yaitu dengan memberi pemahaman pada guru berupa mengadakan rapat atau musyawaroh, karena suatu organisasi tanpa ada musyawaroh akan menimbulkan tidak tercapainya suatu tujuan organisasi, sehingga kepala sekolah mengadakan rapat dengan para guru dan juga perkumpulan dengan para siswa sekaligus orang tua di sekolah secara bergantian mengenai pemahaman pembelajaran sistem daring.

Menambah kegiatan yang sifatnya dapat diperaktikkan secara lansung dirumah Disamping pembelajaran yang sifatnya tertulis dan disertai tugas-tugas belajar siswa guru dapat memberikan tugas tambahan yang sifatnya untuk membuat video pendek membaca surat-surat pendek dalam Al Qur'an.

Dari hasil wawancara, bisa diambil kesimpulan bahwa strategi kepala sekolah dalm peningkatan motivasi belajar siswa SMPN 2 Peterongan pada masa pandemi covid 19 yaitu dngan menambahkan tugas siswa yang sifatnya praktek, misal menghafal surat-surat pendek lalu di kirim berupa video dan juga membuat kaligrafi yang dikirim berupa foto agar siswa tidak monoton menulis, merangkum dan mengerjakan soal-soal saja.

c. Penilaian siswa dalam pelaksanaan pembelajaran daring, menggunakan penilaian lapangan yang bersifat kualitaif yaitu penilaian yang sifatnya membangun motivasi belajar siswa disekolah.

Dari hasil wawancara di atas, bisa diambil kesimpulan bahwa strategi kepala sekolah dalm peningkatan motivasi belajar siswa SMPN 2 Peterongan pada masa panemi covid 19 yaitu memberikan penilaian kepada siswa berupa kualitatif, yaitu kerapian,ketepatan dan kejujuran yang rajin, kurang rajin, tidak rajin dan lain-lain. 


\section{Motivasi belajar siswa pada masa pandemi covid 19 di SMPN 2 Peterongan Jombang}

Sesuai dengan penelitian yang dilaksanakan, peneliti memperoleh data tentang motivasi belajar siswa. Adapun data-data yang di peroleh selama penelitian di SMPN 2 Peterongan Jombang adalah mengenai motivasi belajar siswa pada masa pandemi covid 19.

a. Adanya hasrat dan keinginan berhasil, siswa memiliki keinginan yang kuat untuk berhasil menguasai materi dan mendapatkan nilai yang tinggi dalam kegiatan belajarnya.

Dari hasil wawancara, bisa diambil kesimpulan bahwa motivasi belajar siswa SMPN 2 Peterongan pada masa pandemi covid 19 bisa datang dari guru, yaitu berupa pendampingan, pendekatan, guru yang selalu mengingatkan, menyemangati sehingga siswa memiliki hasrat dan keinginan untuk belajar dan juga menguasai materi, selalu mengerjakan tugas, serta ingin mendapat nilai tinggi.

b. Adanya dorongan dan kebutuhan dalam belajar, siswa merasa senang dan memiliki rasa membutuhkan terhadap kegiatan belajar.

Dari hasil wawancara, bisa diambil kesimpulan bahwa motivasi belajar siswa SMPN 2 Peterongan pada masa pandemi covid 19bisa datang dari guru, yaitu berupa adanya dorongan dari guru, berupa home visit dan juga kegiatan yang lain yang membuat para siswa juga memiliki dorongan dan kebutuhan untuk selalu mengikuti kegiatan pembelajaran.

c. Adanya harapan dan cita-cita masa depan, siswa memiliki harapan dan citacita atas materi yang dipelajarinya.

Dari hasil wawancara, bisa diambil kesimpulan bahwa motivasi belajar siswa SMPN 2 Peterongan pada masa pandemi covid 19 yaitu memiliki citacita dan harapan yang tinggi dengan melalui pengarahan dari para guru yang selalu membina.

d. Adanya penghargaan dalam belajar, siswa merasa termotivasi oleh hadiah atau penghargaan dari guru atau orang-orang disekitarnya atas keberhasilan belajar yang ia capai.

Dari hasil wawancara, bisa diambil kesimpulan bahwa motivasi belajar siswa SMPN 2 Peterongan pada masa pandemi covid 19 yaitu bisa berasal dari hadiah atau penghargaan bagi yang berprestasi, sehingga siswa akan berlomba-lomba untuk belajar dan meraih prestasi.

e. Adanya kegiatan yang menarik dalam belajar, siswa merasa tertarik mengikuti kegiatan pembelajaran.

Dari hasil wawancara, bisa diambil kesimpulan bahwa motivasi belajar siswa SMPN 2 Peterongan pada masa pandemi covid 19 yaitu bisa dari kegiatan 
menarik, misal: lomba secara virtual, lomba menggambar, menyanyi dll. atau pembelajaran yang menarik, misal: video, game, Quize, google form, dll

f. Adanya lingkungan belajar yang kondusif sehingga memungkinkan siswa dapat belajar dengan baik, siswa merasa nyaman pada situasi lingkungan tempat ia belajar.

Dari hasil wawancara, bisa diambil kesimpulan bahwa motivasi belajar siswa SMPN 2 Peterongan pada masa pandemi covid 19 yaitu dengan adanya kondisi linhkungan yang kondusif atau mendukung dan nyaman, sehingga sekolah menyediakan HP bagi yang tidak mampu, kuota gratis dan fasilitas yang menunjang siswa untuk bisa mengikuti pembelajan dengan aktif.

\section{Pembahasan}

\section{Strategi Kepala Sekolah Dalam Peningkatan Motivasi Belajar Siswa Pada Masa Pandemi Covid 19}

Strategi adalah suatu cara atau teknik yang digunakan oleh seorang dalam hal apapun untuk mencapaai sebuah target dalam hal ini kontekstualisasi strategi dalam sebuha pemimpin adalah untuk mencapai tujuan yang diinginkan. Strategi dapat juga diartikan sebagai kiat, cara, mekanisme seorang pemimpin untuk mencapai tujuan dalam kepemimpinananya. ${ }^{13}$

Selanjutnya mengemukan strategi adalah rencana yang disatukan, memperluas dan terintegrasi yang menghubungkan keunggulan strategis perusahaan dengan tantangan lingkungan dan yang dirancang untuk memastikan bahwa tujuan utama dari perusahaan itu dapat dicapai melalui pelaksanaan yang tepat oleh organisasi manajemen strategis dalam sejumlah keputusan dan tindakan yang mengarah pada penyusunan suatu strategi atau sejumlah strategi yang efektif untuk membantu mencapai sasaran perusahaan. ${ }^{14}$ Proses manajemen strategis ialah cara dengan jalan mana para perencanan strategis menentukan sasaran dan mengambil kebijakan.

Strategi kepala sekolah dalam mengambil kebijakan pembelajaran dimasa pandemi adalah: 15

a. Merancang, menentukan, menyusun dan mengimplementasikan pembelajaran untuk mencapai tujuan pembelajaran.

\footnotetext{
13 Ats-Tsauri and Munastiwi, "Strategi Kepala Madrasah Dalam Menentukan Kebijakan Pembelajaran Era Covid 19 Studi Kasus Kepala Madrasah Ibtidaiyah NW Pondok Gedang."

14 Fenty Setiawati, "Manajemen Strategi Untuk Meningkatkan Kualitas Pendidikan," Jurnal AtTadbir: Media Hukum Dan Pendidikan 30, no. 1 (2020): 57-66.

${ }^{15}$ Muflihatusy Syarifah, "Kompetensi Manajerial Kepala Madrasah Di Masa Pandemi Corona Virus Disease Dalam Pelaksanaan Pembelajaran Daring: Penelitian Pada MTS Darussalam WanarajaGarut," AL-KARIM 6, no. 1 (2021): 14-26.
} 
Dalam upaya kepala sekolah membuat sebuah kebijakan pembelajaran agar pembelajaran dimasa pandemi ini dapat berjalan dengan baik, kami dari Lembaga sekolah akan menyususn strategi belajar diluar kelas baik itu dirumah dan di tempat-tempat tertentu dengan berkelompok-kelompok, selain itu strategi belajar yang akan kita gunakan adalah dengan memanfaatkan media sosial sehingga siswa dengan guru dapat berkomunikasi secara lansung media social sehingga pembelajaran dapat berjalan sebagaimana yang kita harapkan.

Menyusun kelompok-kelompok belajar yang dilaksankan di luar sekolah. Kemudian selanjutnya guru dan siswa memanfaatkan media sosial sebagi media pembelajaran untuk memudahkan pembelajaran jarak jauh antara siswa dengan guru dan siswa dengan siswa lainnya. ${ }^{16}$

Dalam perencanaan starategi diera pandemi yang sudah dibuat oleh kepala sekolah adalah persiapan perencanaan strategi dalam pembelajaran daring kepada siswa dengan menggunakan alat media sosial sebagai sarana pembelajaran serta pola pembelajarannya didasarkan pada tujuan yang diharapkan dimana tujuan pembelajaran adalah selain untuk meningkatkan pengetahuan siswa juga bisa merubah kebiasaan atu tingkah laku siswa hal ini sesuai dengan pernyataan kimble dan garmezi tentang pengertian belajar bahwasanya belajar merupakan perubahan tingklah laku yang bersikap tetap yang berlansung dari pengalaman oleh karena itu persiapan yang disusun oleh sekolah hendaknya disesuiakan dengan keadaan dan situasi sekarang ini.

Maka teori di atas memperjelas dan memperkuat dengan hasil penelitian tentang strategi kepala sekolah dalam peningkatan motivasi belajar siswa di SMPN 2 Peterongan Jombang bahwa yaitu dengan membuat perencanan terlebih dahulu, karena suatu manajemen itu pasti diawali dengan perencanaan, di sini kepala sekolah membuat perencanaan mengenai langkah-langkah pembelajarn aktif.

b. Memberikan pemahaman kepada guru dan siswa mengenai mekanisme pembelajaran daring

Implmentasi pembelajaran daring mengacu kepada kebijakan dan peraturan pemerintah dan kebijakan kepala sekolah menganai pembelajaran daring. Dalam situasi dan kondisi yang terjadi saat ini masa pandemic bukanlah menjadi kendala pelaksanaan proses belajar mengajar. Namun

16 Fariza Anggraini and Asrul M Mustaqim, "Pola Interaksi Virtual Guru Dan Orangtua Murid Selama Pembelajaran Jarak Jauh (Pji) Patterns Of Virtual Interaction Between Teachers And Parents During Distance Learning," Jurnal ISIP: Jurnal Ilmu Sosial Dan Ilmu Politik| Vol 17, no. 2 (2020): 50. 
bagaiamana kita mampu membaca situasi dan memanfaatkan media sosial sebagi media pembelajaran sehingga pembelajaran dimasa pandemi ini tetap terlaksana seuai tujuan pembelajaran yang diharapakan.

Dalam mengimplementasikan pembelajaran daring guru atau tenaga pendidik juga harus memberikan pemahaman kepada siswa agar pembelajaran daring yang dilaksanakan sesuai dengan peraturan protokol Kesehatan. ${ }^{17}$

Maka teori di atas memperjelas dan memperkuat dengan hasil penelitian tentang strategi kepala sekolah dalam peningkatan motivasi belajar siswa di SMPN 2 Peterongan Jombang bahwa: dengan memberi pemahaman pada guru berupa mengadakan rapat atau musyawaroh, karena suatu organisasi tanpa ada musyawaroh akan menimbulkan tidak tercapainya suatu tujuan organisasi, sehingga kepala sekolah mengadakan rapat dengan para guru dan juga perkumpulan dengan para siswa sekaligus orang tua di sekolah secara bergantian mengenai pemahaman pembelajaran sistem daring.

c. Menambah kegiatan yang sifatnya dapat diperaktikkan secara lansung dirumah

Di samping pembelajaran yang sifatnya tertulis dan disertai tugastugas belajar siswa guru dapat memberikan tugas tambahan yang sifatnya untuk membuat video pendek membaca surat-surat pendek dalam Al Qur'an.

Maka teori di atas memperjelas dan memperkuat dengan hasil penelitian tentang strategi kepala sekolah dalam peningkatan motivasi belajar siswa di SMPN 2 Peterongan Jombang bahwa: dengan menambahkan tugas siswa yang sifatnya praktek, misal menghafal surat-surat pendek lalu di kirim berupa video dan juga membuat kaligrafi yang dikirim berupa foto agar siswa tidak monoton menulis, merangkum dan mengerjakan soal-soal saja.

d. Penilaian siswa dalam pelaksanaan pembelajaran daring, menggunakan penilaian lapangan yang bersifat kualitaif yaitu penilaian yang sifatnya membangun motivasi belajar siswa di sekolah. ${ }^{18}$

Maka teori di atas memperjelas dan memperkuat dengan hasil penelitian tentang strategi kepala sekolah dalam peningkatan motivasi belajar siswa di SMPN 2 Peterongan Jombang bahwa: memberikan penilaian kepada siswa

\footnotetext{
17 Rifa Afiva Firyal, “Pembelajaran Daring Dan Kebijakan New Normal Pemerintah,” 2020.

18 Ats-Tsauri and Munastiwi, "Strategi Kepala Madrasah Dalam Menentukan Kebijakan Pembelajaran Era Covid 19 Studi Kasus Kepala Madrasah Ibtidaiyah NW Pondok Gedang."
} 
berupa kualitatif, yaitu kerapian,ketepatan dan kejujuran yang rajin, kurang rajin, tidak rajin dll.

\section{Motivasi Belajar Siswa Pada Masa Pandemi Covid 19}

Sardiman mendefinisikan bahwa motivasi belajar adalah keseluruhan daya penggerak di dalam diri siswa yang menimbulkan kegiatan belajar, yang menjamin keberlangsungan dari kegiatan belajar dan memberi arah pada kegiatan belajar, sehingga tujuan yang dikehendaki oleh subjek dapat tercapai. ${ }^{19}$ Indikator motivasi belajar menurut Hamzah B. Uno dapat diklasifikasikan sebagai berikut:20 Pertama, Adanya hasrat dan keinginan berhasil, siswa memiliki keinginan yang kuat untuk berhasil menguasai materi dan mendapatkan nilai yang tinggi dalam kegiatan belajarnya. Maka teori di atas memperjelas dan memperkuat dengan hasil penelitian tentang indikator motivasi belajar siswa di SMPN 2 Peterongan Jombang bahwa: berupa adanya pendampingan guru, pendekatan guru, guru yang selalu mengingatkan, menyemangati sehingga siswa memiliki hasrat dan keinginan untuk belajar dan juga menguasai materi, selalu mengerjakan tugas, serta ingin mendapat nilai tinggi. Kedua, Adanya dorongan dan kebutuhan dalam belajar, siswa merasa senang dan memiliki rasa membutuhkan terhadap kegiatan belajar. ${ }^{21}$

Maka teori di atas memperjelas dan memperkuat dengan hasil penelitian tentang indikator motivasi belajar siswa di SMPN 2 Peterongan Jombang bahwa: adanya dorongan dari guru, berupa home visit dan juga kegiatan yang lain yang membuat para siswa juga memiliki dorongan dan kebutuhan untuk selalu mengikuti kegiatan pembelajaran.

c. Adanya harapan dan cita-cita masa depan, siswa memiliki harapan dan citacita atas materi yang dipelajarinya.

Maka teori di atas memperjelas dan memperkuat dengan hasil penelitian tentang indikator motivasi belajar siswa di SMPN 2 Peterongan Jombang bahwa: memiliki cita-cita dan harapan yang tinggi dengan melalui pengarahan dari para guru yang selalu membina.

d. Adanya penghargaan dalam belajar, siswa merasa termotivasi oleh hadiah atau penghargaan dari guru atau orang-orang disekitarnya atas keberhasilan belajar yang ia capai. ${ }^{22}$

\footnotetext{
${ }^{19}$ Arief M Sardiman, "Interaksi \& Motivasi Belajar Mengajar," 2020.

${ }^{20}$ Hamzah B Uno and Teori Motivasi, "Pengukurannya (Analisis Di Bidang Pendidikan)," Jakarta: PT Bumi Akasara, 2011.

${ }^{21}$ Shilphy A Octavia, Motivasi Belajar Dalam Perkembangan Remaja (Deepublish, 2020).

${ }^{22}$ Moch. Sya'roni Hasan and Alahum, "Pengaruh Penerapan Punishment Terhadap Akhlak Santri Putra Di Pondok Pesantren Al Urwatul Wutsqo Bulurejo Diwek Jombang," Jurnal Ilmuna: Jurnal
} 
Maka teori di atas memperjelas dan memperkuat dengan hasil penelitian tentang indikator motivasi belajar siswa di SMPN 2 Peterongan Jombang bahwa: bisa berasal dari hadiah atau penghargaan bagi yang berprestasi, sehingga siswa akan berlomba-lomba untuk belajar dan meraih prestasi.

e. Adanya kegiatan yang menarik dalam belajar, siswa merasa tertarik mengikuti kegiatan pembelajaran. ${ }^{23}$

Maka teori di atas memperjelas dan memperkuat dengan hasil penelitian tentang indikator motivasi belajar siswa di SMPN 2 Peterongan Jombang bahwa: bisa dari kegiatan menarik, misal: lomba secara virtual, lomba menggambar, menyanyi dll. atau pembelajaran yang menarik, misal: video, game, Quize, google form, dll.

f. Adanya lingkungan belajar yang kondusif sehingga memungkinkan siswa dapat belajar dengan baik, siswa merasa nyaman pada situasi lingkungan tempat ia belajar. ${ }^{24}$

Maka teori di atas memperjelas dan memperkuat dengan hasil penelitian tentang indikator motivasi belajar siswa di SMPN 2 Peterongan Jombang bahwa: adanya kondisi lingkungan yang kondusif atau mendukung dan nyaman, sehingga sekolah menyediakan HP bagi yang tidak mampu, kuota gratis dan fasilitas yang menunjang siswa untuk bisa mengikuti pembelajan dengan aktif.

\section{Kesimpulan}

Strategi kepala sekolah SMPN 2 Peterongan dalam peningkatan motivasi belajar siswa pada masa pandemi covid 19 adalah Kepala sekolah membuat perencanaan mengenai langkah-langkah pembelajarn aktif. Kepala sekolah mengadakan rapat dengan para guru dan juga perkumpulan dengan para siswa sekaligus orang tua di sekolah secara bergantian mengenai pemahaman pembelajaran sistem daring. Menambahkan tugas kepada siswa yang sifatnya praktek di rumah. Memberikan penilaian kepada siswa berupa kualitatif, yaitu kerapian, ketepatan dan kejujuran yang rajin, kurang rajin, tidak rajin dan lainlain. Sedangkan Motivasi belajar yang dimiliki siswa di SMPN 2 Peterongan

Studi Pendidikan Agama Islam, 2020,

https://jurnal.stituwjombang.ac.id/index.php/ilmuna/article/view/149.

${ }^{23}$ Indah Sari, "Motivasi Belajar Mahasiswa Program Studi Manajemen Dalam Penguasaan Keterampilan Berbicara (Speaking) Bahasa Inggris," Jumant 9, no. 1 (2018): 41-52.

${ }^{24}$ Moch. Sya'roni Hasan, "Implikasi Kejenuhan (Burnout) Belajar Terhadap Minat Belajar Peserta Didik Pada Mata Pelajaran Pendidikan Agama Islam Di SMP Negeri 2 Diwek Jombang | Al Hikmah: Jurnal Studi Keislaman," Al Hikmah: Jurnal Studi Keislaman, 2020, http://ejournal.kopertais4.or.id/pantura/index.php/alhikmah/article/view/3493. 
Jombang pada masa pandemi covid 19 adalah siswa memiliki hasrat dan keinginan berhasil, dorongan dan kebutuhan dalam belajar, harapan dan cita-cita masa depan, termotivasi dengan penghargaan dalam belajar, termotivasi dengan kegiatan yang menarik dalam belajar, dan juga dengan lingkungan belajar yang kondusif.

\section{Daftar Pustaka}

Anggraini, Fariza, and Asrul M Mustaqim. "Pola Interaksi Virtual Guru Dan Orangtua Murid Selama Pembelajaran Jarak Jauh (Pjj) Patterns Of Virtual Interaction Between Teachers And Parents During Distance Learning." Jurnal ISIP: Jurnal Ilmu Sosial Dan Ilmu Politik| Vol 17, no. 2 (2020): 50.

Ats-Tsauri, Muhammad Sufyan, and Erni Munastiwi. "Strategi Kepala Madrasah Dalam Menentukan Kebijakan Pembelajaran Era Covid 19 Studi Kasus Kepala Madrasah Ibtidaiyah NW Pondok Gedang." Elementeris: Jurnal Ilmiah Pendidikan Dasar Islam 2, no. 2 (2020): 55-61.

Farmawati, Cintami, and Siti Nureliza. "Ketrampilan Komunikasi Guru Dalam Meningkatkan Motivasi Belajar Siswa Di Kelompok Bermain Mahardika." Jurnal Lentera Anak 1, no. 01 (2020).

Firyal, Rifa Afiva. "Pembelajaran Daring Dan Kebijakan New Normal Pemerintah," 2020.

Hasan, Moch. Sya'roni. “Implikasi Kejenuhan (Burnout) Belajar Terhadap Minat Belajar Peserta Didik Pada Mata Pelajaran Pendidikan Agama Islam Di SMP Negeri 2 Diwek Jombang | Al Hikmah: Jurnal Studi Keislaman." Al Hikmah : Jurnal Studi Keislaman, 2020. http://ejournal.kopertais4.or.id/pantura/index.php/alhikmah/article/view /3493.

Hasan, Moch. Sya'roni, and Alahum. "Pengaruh Penerapan Punishment Terhadap Akhlak Santri Putra Di Pondok Pesantren Al Urwatul Wutsqo Bulurejo Diwek Jombang." Jurnal Ilmuna: Jurnal Studi Pendidikan Agama Islam, 2020. https://jurnal.stituwjombang.ac.id/index.php/ilmuna/article/view/149.

KEBUDAYAAN, MPDAN, and REPUBLIK INDONESIA. "Surat Edaran Nomor 4 Tahun 2020 Tentang Pelaksanaan Kebijakan Pendidikan Dalam Masa Darurat Penyebaran Coronavirus Disease (COVID-19)." Khomariyah, KN, E Afia, UN (2020). Digitalisasi Dalam Proses Pembelajaran Sebagai Dampak Era Keberlimpahan. ISoLEC Proceedings 4, no. 1 (2020): 72-76.

Khodijah, Siti, and Mohammad Syahidul Haq. "Strategi Kepemimpinan Kepala Sekolah Dalam Meningkatkan Mutu Pendidikan Di Masa Pandemi Covid-19," n.d.

Mahardika, Serli, and Fery Setyaningrum. "Analisis Faktor Penyebab Kesulitan Belajar Pada Pembelajaran Bahasa Jawa Kelas V Sd Muhammadiyah Bausasran Ii Yogyakarta." Jurnal Fundadikdas (Fundamental Pendidikan Dasar) 3, no. 3 (2020): 251-59.

Moleong, Lexy J. Metodologi Penelitian Kualitatif. PT Remaja Rosdakarya, 2021. 
Noer, Syaifudin, Evi Fatimatur Rusydiyah, and Fachrizal Hamzah. "Model Ilhamq (Model Menghafal Al Quran Berbasis Game) Di SMP Insan Cendekia Mandiri Boarding School Sidoarjo." Nusantara Journal of Islamic Studies (NJIS) 1, no. 2 (2020): 1-10.

Octavia, Shilphy A. Motivasi Belajar Dalam Perkembangan Remaja. Deepublish, 2020. Sardiman, Arief M. “Interaksi \& Motivasi Belajar Mengajar," 2020.

Sari, Buana, Baiq Arnika Sa'adati, and Muhamad Sadli. "Peningkatan Motivasi Belajar Siswa Melalui Penerapan Metode Hypnoteaching Pada Mata Pelajaran Ips Siswa Kelas V Sd Nurul Ijtihad Pujut Lombok Tengah." Elementeris: Jurnal Ilmiah Pendidikan Dasar Islam 1, no. 2 (2019): 10-18.

Sari, Indah. "Motivasi Belajar Mahasiswa Program Studi Manajemen Dalam Penguasaan Keterampilan Berbicara (Speaking) Bahasa Inggris." Jumant 9, no. 1 (2018): 41-52.

Setiawati, Fenty. "Manajemen Strategi Untuk Meningkatkan Kualitas Pendidikan." Jurnal At-Tadbir: Media Hukum Dan Pendidikan 30, no. 1 (2020): 57-66.

Sugiyono, Dr. "Metode Penelitian Pendidikan Pendekatan Kuantitatif, Kualitatif Dan R\&D," 2013.

Syarifah, Muflihatusy. "Kompetensi Manajerial Kepala Madrasah Di Masa Pandemi Corona Virus Disease Dalam Pelaksanaan Pembelajaran Daring: Penelitian Pada MTS Darussalam Wanaraja-Garut." AL-KARIM 6, no. 1 (2021): 14-26.

Taufan, Johandri, and Fachri Mazhud. "Kebijakan-Kebijakan Kepala Sekolah Dalam Penyelenggaraan Pendidikan Inklusif Di Sekolah X Kota Jambi." Jurnal Penelitian Pendidikan 14, no. 1 (2016).

Uno, Hamzah B, and Teori Motivasi. "Pengukurannya (Analisis Di Bidang Pendidikan)." Jakarta: PT Bumi Akasara, 2011. 